\title{
Measurement and interpretation of gas phase formaldehyde concentrations obtained during the CHABLIS campaign in coastal Antarctica
}

\author{
R. A. Salmon ${ }^{1}$, S. J.-B. Bauguitte ${ }^{1}$, W. Bloss ${ }^{2}$, M. A. Hutterli ${ }^{1}$, A. E. Jones ${ }^{1}$, K. Read ${ }^{3}$, and E. W. Wolff ${ }^{1}$ \\ ${ }^{1}$ British Antarctic Survey, High Cross, Madingley Road, Cambridge, CB3 0ET, UK \\ ${ }^{2}$ School of Geography, Earth \& Environmental Sciences, University of Birmingham, Edgbaston, Birmingham, B15 2TT, UK \\ ${ }^{3}$ Department of Chemistry, University of York, Heslington, York YO19 4RR, UK
}

Received: 10 December 2007 - Published in Atmos. Chem. Phys. Discuss.: 8 February 2008

Revised: 13 June 2008 - Accepted: 24 June 2008 - Published: 29 July 2008

\begin{abstract}
Gas phase formaldehyde concentrations were measured during the 2004-2005 CHABLIS campaign at Halley research station, Antarctica. Data coverage span from May 2004 through to January 2005, thus capturing the majority of the year, with a wintertime minimum of near or below the instrumental detection limit rising to between 50 and $200 \mathrm{pptv}$ during the austral summer. Factors controlling HCHO concentration include local chemical sources and sinks, and exchange with the snow surface. The measured seasonality is in line with previous observations from Neumayer station, with maximum in summer and minimum during the winter months, but with lower absolute concentrations throughout the year. The gas-phase production of $\mathrm{HCHO}$ was dominated by methane oxidation and a steadystate analysis showed that reactions of iodine and bromine species substantially reduced the predicted HCHO levels based upon in situ chemistry. This indicates a substantial additional HCHO source to be present that could be explained by a snowpack source.
\end{abstract}

\section{Introduction}

Formaldehyde (HCHO) is an intermediate species formed during the photochemical oxidation of atmospheric hydrocarbons by hydroxyl radicals. Its formation and destruction is closely linked to odd-hydrogen $\left(\mathrm{HO}_{\mathrm{x}}=\mathrm{HO}_{2}+\mathrm{OH}\right)$ chemistry and, by definition, to the oxidising capacity of the troposphere.

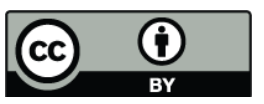

Correspondence to: R. A. Salmon (ipy.ras@gmail.com)
Formaldehyde is an impurity held within precipitated snow and ice, and with its link to boundary layer oxidation processes, it was for many years hoped that an analysis of formaldehyde in ice cores would yield information on how the oxidation capacity of the atmosphere, and specifically $\mathrm{OH}$ concentrations, has changed through time (Staffelbach et al., 1991). However, studies of HCHO in polar regions have shown that there are significant post-depositional processes that need to be considered. Formaldehyde is both lost from the snowpack through physical processes (e.g. Hutterli et al., 1999; Couch et al., 2000; Burkhart et al., 2002; Hutterli et al., 2002; Hutterli et al., 2003) and also generated within and then released from the snowpack through photochemical processes (e.g. Sumner and Shepson, 1999; Sumner et al., 2002; Grannas et al., 2002, 2004; Dassau et al., 2002). The results are two-fold: firstly formaldehyde is not the straight forward ice core proxy for changing oxidative capacity that was originally thought, and secondly, the snowpack in polar regions is a major source of formaldehyde to the polar boundary layer.

There have been several studies of formaldehyde concentrations in the Arctic initially directed at understanding its role in background tropospheric chemistry (e.g. De Serves, 1994; Shepson et al., 1996), and latterly to assess its contribution, via the snowpack, as a source of $\mathrm{HO}_{\mathrm{x}}$ (e.g. Sumner and Shepson, 1999; Sumner et al., 2002; Hutterli et al., 2001; Chen et al., 2007; Sjostedt et al., 2007, Jacobi et al., 2002, Yang et al., 2002). Photolysis of HCHO is not the only high latitude $\mathrm{OH}$ source; snowpack emissions of $\mathrm{H}_{2} \mathrm{O}_{2}$ (Hutterli et al., 2001; Chen et al., 2004; Hutterli et al., 2004; Chen et al., 2007) and HONO (Zhou et al., 2001; Yang et al., 2002; Beine et al., 2006) are also expected to enhance $\mathrm{OH}$ levels, and photolysis of $\mathrm{O}_{3}$ is the primary gas-phase source. The relative contribution from $\mathrm{HCHO}$ has been found to vary at

Published by Copernicus Publications on behalf of the European Geosciences Union. 
Table 1. Mean Monthly Formaldehyde Measurements, Halley Research Station, 2004-5. Daily and monthly averages were determined from 10 minute measurements (see text). $N=$ number of 10 min averages used for monthly mean. LOD = Limit of Detection (twice standard error), see text. All values are given in parts per billion by volume.

\begin{tabular}{lrrrrrr}
\hline Month & Mean & Sdev & Min & Max & N & Mean LOD \\
\hline May 04 & 0.013 & 0.022 & -0.097 & 0.103 & 1501 & 0.002 \\
June 04 & 0.035 & 0.055 & -0.224 & 0.209 & 2338 & 0.017 \\
July 04 & 0.062 & 0.083 & -0.251 & 0.289 & 1702 & 0.019 \\
August 04 & 0.031 & 0.052 & -0.150 & 0.223 & 2329 & 0.016 \\
September 04 & -0.001 & 0.052 & -0.219 & 0.152 & 2256 & 0.019 \\
October 04 & 0.051 & 0.050 & -0.226 & 0.238 & 3224 & 0.016 \\
November 04 & 0.071 & 0.059 & -0.199 & 0.358 & 3204 & 0.029 \\
December 04 & 0.090 & 0.062 & -0.139 & 0.411 & 1755 & 0.018 \\
January 05 & 0.142 & 0.063 & -0.768 & 0.375 & 2705 & 0.021 \\
February 05 & 0.097 & 0.032 & -0.004 & 0.215 & 1059 & 0.015 \\
\hline
\end{tabular}

different sites and also from season to season. For example, during early spring at Summit, Greenland, emissions of $\mathrm{HCHO}$ and $\mathrm{H}_{2} \mathrm{O}_{2}$ from the snow were the dominant source of $\mathrm{OH}$ to the boundary layer (Sjostedt et al., 2005); during the summer, photolysis of $\mathrm{O}_{3}$ became more important and, together with snow-emitted $\mathrm{H}_{2} \mathrm{O}_{2}$, provided the most important route for $\mathrm{HO}_{\mathrm{x}}$ formation (Chen et al., 2007).

Snowpack emissions of HCHO have also been assessed at various locations across Antarctica including South Pole (Hutterli et al., 2002; Chen et al., 2004; Hutterli et al., 2004), Dome C (Hutterli et al., 2002), as well as on the ITASE traverse across the West Antarctic Ice Sheet between $76^{\circ} \mathrm{S}$ and $90^{\circ} \mathrm{S}$ (Frey et al., 2005). As in the Arctic, the role played by HCHO is significant; for example at South Pole, data from the 2000 summer measurement programme showed that emissions of $\mathrm{H}_{2} \mathrm{O}_{2}$ and $\mathrm{HCHO}$ were the dominant $\mathrm{HO}_{\mathrm{x}}$ source (Chen et al., 2004). These studies were restricted to the summer months and only one previous study has aimed to measure Antarctic boundary layer $\mathrm{HCHO}$ on any extended timescale. These measurements were carried out at Neumayer station in coastal Antarctica, where HCHO was measured from March 1997 to January 1998 (Riedel et al., 1999). The aim of the latter study was to probe the magnitude and seasonality of this important radical precursor. The results showed a summer maximum in HCHO (albeit with significant short-term variability) and a wintertime minimum; the range in mixing ratios was roughly 0.1 parts per billion by volume (ppbv) to $0.5 \mathrm{ppbv}$ over the course of the year. The field measurements were followed up by a modelling assessment to deduce the source and sink contributions to ambient HCHO (Riedel et al., 2005), but there were some difficulties reconciling the observations with model calculations.

The measurements presented here were carried out as part of the Chemistry of the Antarctic Troposphere and the Interface with Snow (CHABLIS) campaign that ran at the British Antarctic Survey station, Halley $\left(75^{\circ} 35^{\prime} \mathrm{S}, 26^{\circ} 39^{\prime} \mathrm{W}\right)$, in the Weddell Sea sector of coastal Antarctica from January 2004 to February 2005 (Jones et al., 2007). The campaign aimed to measure a wide range of trace gases and for an extended period of time, to assess changes in chemical composition on seasonal timescales. Of relevance here is that the observation suite included measurements of non-methane hydrocarbons (NMHCs), surface $\mathrm{O}_{3}, \mathrm{NO}, \mathrm{NO}_{2}$, and $\mathrm{OH} / \mathrm{HO}_{2}$ (the latter during summertime only). A full description of the site location and campaign details are provided elsewhere (Jones et al., 2008).

\section{Experimental}

The formaldehyde measurements were made in-situ at the Clean Air Sector Laboratory (CASLab), the Halley atmospheric chemistry laboratory. The CASLab is located $1 \mathrm{~km}$ away from station generators in a sector that receives minimal contamination from the main base. Contamination episodes were monitored using both a Condensation Particle Counter (CPC) and an Aethalometer (which measures black carbon). Formaldehyde data points were removed whenever a local contamination source was evident.

The formaldehyde measurements were made using an Aerolaser 4021 Analyser which has a stated detection limit of $<0.05$ parts per billion by volume (ppbv). It is therefore ideally suited for Antarctic work where boundary layer mixing ratios of HCHO are likely to be low. Ambient air was sampled continuously via a $1.8 \mathrm{~m}$ long, $1 / 4^{\prime \prime}$ o.d. PFA Teflon inlet line which was attached to the main trace-gas manifold in the CASLab (for details see Jones et al., 2008). Data were recorded every $30 \mathrm{~s}$ and further averaged in 10 minute intervals to improve precision. The instrumental detection limit was estimated as twice the 2-sigma standard error of 10 minute means. It varied between 0.01 and $0.06 \mathrm{ppbv}$ throughout the year, with a mean value of $0.018 \mathrm{ppbv}$, due to changes in operational parameters and auto-tuning adjustments by the instrument. This is less than half the manufacturers stated limit. The consistency of this precision throughout the year 
is demonstrated by monthly mean standard deviation values (Table 1) that vary between $0.022 \mathrm{ppbv}$ and $0.063 \mathrm{ppbv}$, with the exception of July when there were known instrumental difficulties. The accuracy, determined by calibration factors discussed below, was $15 \%$.

The continuous measurement technique used has been described in detail elsewhere (Dong and Dasgupta, 1987; Dasgupta et al., 1988; Riedel et al., 1999). Gaseous formaldehyde is scrubbed into the liquid phase via a stripping coil containing dilute sulphuric acid. This is followed by reaction with Hantzsch reagent, a dilute solution made with acetyl acetone, acetic acid, and ammonium acetate. Aqueous-phase formaldehyde reacts with this reagent via the "Hantzsch Reaction" to produce 3,5-diacetyl-1,4-dihydrolutidine (DDL). Once excited by an appropriate wavelength, DLL fluoresces thus allowing quantitative assay by monitoring the emitted light. In our system, excitation was achieved using the $400 \mathrm{~nm}$ line from an Hg lamp, and emission was monitored at $510 \mathrm{~nm}$.

During the campaign, gaseous $\mathrm{HCHO}$ was stripped from a $1 \mathrm{~L} / \mathrm{min}$ (STP) air flow by dilute sulphuric acid flowing at $0.2-0.3 \mathrm{ml} / \mathrm{min}$. The air flow was calibrated and controlled with a mass flow controller, and liquid flow was measured routinely. The system was calibrated by emitting a gas phase pulse of HCHO, produced from an internal wafer in the instrument, every $9 \mathrm{~h}$, and by passing the air through a hydrocarbon trap to produce a zero signal every $3 \mathrm{~h}$. This zero was also confirmed by attaching an external scrubber to the inlet line 2-3 times per week.

In order to correctly derive $\mathrm{HCHO}$ mixing ratios, it is critical to accurately know the emission rate from the internal wafer. In order to do this, work was carried out in the UK after the Antarctic measurement campaign to determine the emission rate. This was done using two different methods: (a) gas phase calibration, (b) liquid phase calibration + collection efficiency experiments.

Method a): The gas phase calibration method used a Kintech Model 491-M HCHO gas calibrator to supply a known concentration of $\mathrm{HCHO}$ in air. A range of concentrations from the Kintech source were passed into the AL4021, via the same inlet tube as was used in the field, and the signals compared with that from the AL4021 internal gas source, as shown in Fig. 1. This method accounts for gas phase losses in the system, and determined an emission rate from the internal wafer of $10.43 \mathrm{ng} / \mathrm{min} \pm 15 \%$ (Fig. 1). The manufacturer's systematic error of $15 \%$ is due to the dynamic mass flow controlled dilution and stability control of the permeation oven that both influence the permeation rate of the Kintech gas calibrator.

Method $b$ ): The liquid technique involved comparing the internal wafer calibration pulse with a calibration curve determined from liquid standards and yielded an emission rate from the internal wafer of $8.507 \mathrm{ng} / \mathrm{min} \pm 12 \%$. (The experimental error was determined from the liquid titration results). However, this method does not account for losses in collec-

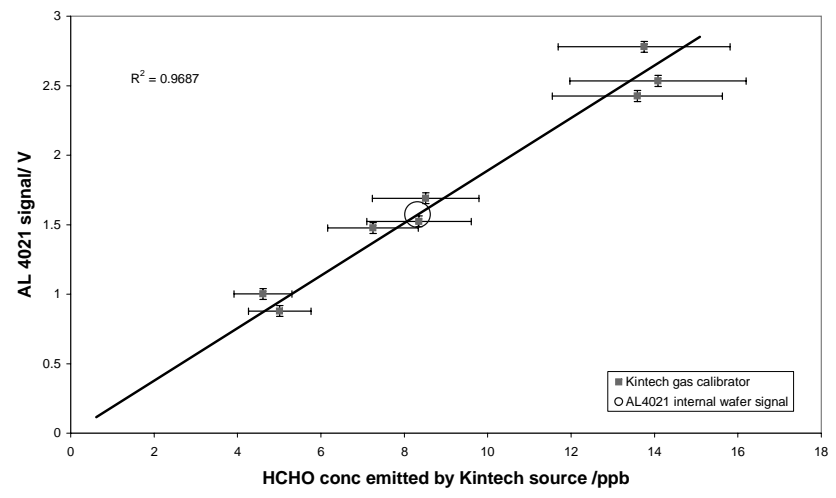

Fig. 1. Gas Calibration of AL4021 HCHO Analyser. Error from Kintech $\mathrm{HCHO}$ source $15 \%$, error bars show $2 \sigma$ variation of repeated calibrations, Pearson's linear correlation coefficiant, $R^{2}=0.9687$.

tion or gas scrubbing (i.e. the collection efficiency) so this value is known to be an underestimate. In order to provide a correction factor, collection efficiency experiments were conducted. Calibration gas from the internal wafer was passed through four bubblers in series, each containing MilliQ water $(18 \mathrm{M} \mathrm{Ohm} / \mathrm{cm})$ and then directed into the AL4021 to monitor any residual signal. After about $50 \mathrm{~min}$, the contents of each bubbler were analyzed for dissolved $\mathrm{HCHO}$ using the AL4021 Analyser in liquid measurement mode. The collection efficiency was determined by comparing the total $\mathrm{HCHO}$ collected in the bubblers over a specific time period with that measured by the instrument with no bubblers. The collection efficiency derived experimentally in this fashion was $0.85 \pm 0.04$. We note that this value compares well with the collection efficiency calculated by comparing the emission rate derived from the bubbler method with that from the Kintech method (collection efficiency $=0.815 \pm 0.22$ ). Knowing the collection efficiency allows a correction to be made to the liquid phase calibration, which must be increased by a factor $1 / 0.85$. The corrected emission rate from the internal wafer derived by liquid phase calibration therefore equals $10.0 \pm 1.67 \mathrm{ng} / \mathrm{min}$. It was decided to use this value, from method (b), for determination of gas phase concentrations due to the improved precision as compared to method (a).

In order to correctly derive measurements from the $\mathrm{HCHO}$ analyzer it is essential to characterize and understand the instrument operation parameters. The results from this study gives considerable reassurance that the calibrations used to derive the $\mathrm{HCHO}$ data presented here are robust.

\section{Results and discussion}

Results from the year-round measurement are shown in Fig. 2 with monthly summary statistics in Table 1 . Daily and monthly averages were determined from $10 \mathrm{~min}$ measurements. During the austral winter, when there was no direct 


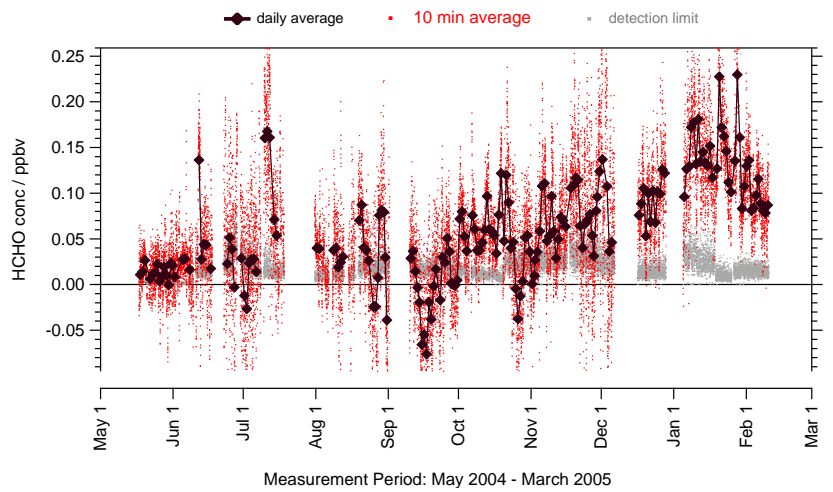

Fig. 2. Year-round gas phase formaldehyde measurements, Halley Research Station, 2004-5. Black diamonds and line are daily averages (parts per billion by volume), $10 \mathrm{~min}$ averages shown as red dots, limit of detection (twice standard error) shown in grey.

sunlight and little local chemistry occurring, the HCHO concentrations remained close to, or below, the instrumental detection limit. Concentrations increased during spring and reached a maximum in the austral summer when there was continual sunlight and very active local photochemistry (e.g. Bloss et al., 2007). Summer concentrations (NovemberFebruary), remained between 50-200 pptv. The seasonality of the Halley data is therefore the same as the earlier measurements made at Neumayer, but the magnitudes recorded are significantly different. Indeed, the Neumayer measurements (Riedel et al., 1999) are approximately three to four times higher than the Halley data set.

There are no obvious differences between the two study sites; Halley and Neumayer are both coastal stations in the Weddell Sea Sector of Antarctica. They are therefore both exposed to a mix of continental and maritime air and have similar seasonal range of temperatures (König-Langlo et al., 1998). Because both sites are on relatively narrow coastal ice shelves, we have no reason to expect the boundary layer height and other factors such as open water leads to differ. A potential source for the differences lies in the analytical approaches adopted. While the instruments used to obtain the data were almost identical (the Neumayer study used an Aerolaser AL4001, an earlier version of the Aerolaser AL4021 employed at Halley), the calibration methods were different. Both methods added a sample of calibration gas, produced internally by the instrument, to zero air at regular intervals. Both also took regular readings of zero air to ensure a consistent monitoring of the baseline. The instrument at Neumayer, however, was calibrated during the campaign by using a liquid standard to which the gas calibrant was compared. Although this method was also employed during the CHABLIS campaign at Halley, post-analysis of the data suggested that the variability of the internal calibrations of the liquid standard was greater than the variation of the gas signal itself. This was partially due to instru- mental auto-calibration parameters that changed sensitivity following calibrations. In addition (and as outlined above), this method did not account for internal losses of gas phase HCHO prior to the Hantzsch reaction used for quantification. The Halley data were therefore calibrated assuming a constant gas permeation rate throughout the campaign. The permeation rate used was shown to be within the error both prior to, and following, the campaign. Furthermore, the Neumayer data were derived assuming a collection efficiency of $99.9 \%$ based on the manufacturers specifications. The analysis presented here shows that the Halley instrument had a lower collection efficiency, and that data derived from liquid calibrations required an additional correction factor to be applied. Unaccounted losses during sampling and scrubbing would however not explain the higher measurements from the Neumayer data set. The difference between these data sets is unresolved and cannot be explained by instrumental differences alone.

In a follow-up modelling study, Riedel et al. (2005) explored the sources of $\mathrm{HCHO}$ that could contribute to their observed values. In addition to standard gas phase chemistry, they considered the contribution from isoprene, ethene, propene, dimethyl sulphide (DMS), as well as the role from halogens (with $\mathrm{Cl}+\mathrm{CH}_{4}$ as a source, and sinks from $\mathrm{Br}+\mathrm{HCHO}$ and $\mathrm{BrO}+\mathrm{HCHO}$ ). They also looked to emission fluxes from the snowpack as a means of reconciling their measurements. The model studies were carried out for the month of November, the monthly maximum in their annual observations. Their assumed precursor concentrations were based on measurements made elsewhere, as such supporting data were not available from Neumayer. The basic scenario included 100 pptv DMS, $5 \times 10^{3}$ molecs cm $\mathrm{cm}^{-3} \mathrm{Cl}$ atoms, $1.5 \times 10^{6}$ molecs $\mathrm{cm}^{-3} \mathrm{Br}$ atoms, and had two NMHC scenarios; respectively isoprene at 60 or $5 \mathrm{pptv}$, propene at 24 or $10 \mathrm{pptv}$, ethene at 45 or $25 \mathrm{pptv}$. They concluded that, even using the higher NMHC loading, gas phase production could account for a maximum of $37 \%$ of the observed $\mathrm{HCHO}$; the flux from the snowpack required to fill the gap, assuming a boundary layer height of $41.5 \mathrm{~m}$, was $1.9 \times 10^{13}$ molecs $\mathrm{m}^{-2} \mathrm{~s}^{-1}$. For the lower NMHC scenario, the snowpack source required to account for observed $\mathrm{HCHO}$ increased to $2.5 \times 10^{13}$ molecs $\mathrm{m}^{-2} \mathrm{~s}^{-1}$. Methane oxidation contributed between 9 and $14.8 \%$ to the observed HCHO.

A significant advantage of the CHABLIS campaign is that it included simultaneous measurements of a wide range of trace gases. These can be used in numerical assessments to constrain the calculations to observed values. Here we present steady state calculations that use concurrent measurements as input, and explore the sources and sinks of HCHO at Halley. 
Table 2. Relative potential $\mathrm{HCHO}$ production from $\mathrm{OH}$-initiated VOC oxidation.

\begin{tabular}{lccc}
\hline Species $^{\mathrm{a}}$ & $k^{\prime}(\mathrm{OH})^{\mathrm{b} / \mathrm{s}^{-1}}$ & HCHO production potential & Contributionto potential HCHO production/\% \\
\hline Methane & 0.149 & 1 & 79.25 \\
iso-Butene & $2.91 \times 10^{-3}$ & 4 & 6.19 \\
Propene & $2.68 \times 10^{-3}$ & 3 & 4.28 \\
DMS & $3.56 \times 10^{-3}$ & 2 & 3.79 \\
Ethene & $2.47 \times 10^{-3}$ & 2 & 2.63 \\
Methanol & $4.43 \times 10^{-3}$ & 1 & 2.35 \\
Propane & $3.09 \times 10^{-4}$ & 3 & 0.49 \\
Ethane & $4.19 \times 10^{-4}$ & 2 & 0.45 \\
Trans-2-Butene & $1.45 \times 10^{-4}$ & 4 & 0.31 \\
Benzene & $3.35 \times 10^{-5}$ & 6 & 0.11 \\
n-Butane & $3.08 \times 10^{-5}$ & 4 & 0.07 \\
Iso-Butane & $2.24 \times 10^{-5}$ & 4 & 0.05 \\
1-Butene & $8.55 \times 10^{-6}$ & 4 & 0.02 \\
Acetylene & $1.43 \times 10^{-5}$ & 2 & 0.02 \\
\hline
\end{tabular}

${ }^{a} \mathrm{CH}_{4}$ data from CMDL flask analyses (Dlugokencky et al., 2007); $\mathrm{CH}_{3} \mathrm{OH}$ (200 ppt, taken from Jacob et al., 2005); NMHC data measured via GC-FID (Read et al., 2007).

${ }^{\mathrm{b}} k^{\prime}$ is pseudo-first-order rate coefficient for reaction with $\mathrm{OH}$, calculated using temperature-dependent rate constants taken from the IUPAC evaluation (Atkinson et al., 2006).

\section{Steady state source and sink calculations}

The HCHO levels observed in the Antarctic boundary layer at Halley result from a combination of in situ photochemical production and loss, effects of the snowpack (which can be a source or a sink for carbonyl species), and production/loss due to mixing of overlying air from the free troposphere. The suite of observations obtained during the CHABLIS project allow the in situ contributions to HCHO to be constrained, which together with the $\mathrm{HCHO}$ observations permit the net external flux (snowpack plus mixing) to be obtained.

The measurements required for these calculations, notably observations of $\mathrm{HO}_{\mathrm{x}}$, were available during the (austral) summer 2005 measurement period, corresponding to 3 January-10 February 2005; the following calculations refer to this period of the campaign.

Formaldehyde production results primarily from the $\mathrm{OH}-$ initiated degradation of hydrocarbons. NMHC were measured during CHABLIS via GC-FID (Read et al., 2007), while methane abundance (1720 ppb for January 2005) was determined through flask analyses by the Climate Monitoring and Diagnostics Laboratory (Dlugokencky et al., 2007). An indication of the relative potential for $\mathrm{HCHO}$ production from each parent hydrocarbon species measured can be obtained by comparing the product of their reaction rates with $\mathrm{OH}$, with the maximum number of possible $\mathrm{HCHO}$ molecules which may ultimately result, conserving carbon i.e. 1 for methane, 3 for propene etc. Table 2 shows the result of this calculation for the summer measurement period.
The potential HCHO production is clearly dominated by oxidation of methane (nearly $80 \%$ of the total). It should be noted that this approach will overestimate the HCHO production for larger hydrocarbons, as the degradation products from such species may be removed from the atmospheric system by deposition, mixing etc. in the course of their chemical processing, thus the relative contribution of $\mathrm{CH}_{4}$ to the in situ chemical production of $\mathrm{HCHO}$ at Halley is likely to be greater than this calculation indicates. A more accurate approach to calculation of the $\mathrm{HCHO}$ production would be to consider the actual $\mathrm{HCHO}$ yield anticipated from the oxidation of each of the measured VOCs, and from successive generations of their daughter compounds (e.g. Wert et al., 2003; Lee et al., 1998), however the dominance of $\mathrm{CH}_{4}$ over NMHCs for HCHO production in this environment, and the uncertainties in the halogen reactions removing HCHO (see below) are such that the simple approach is appropriate.

In the remote boundary layer, the $\mathrm{CH}_{4}+\mathrm{OH}$ reaction leads to production of $\mathrm{CH}_{3} \mathrm{O}_{2}$, which conventionally is considered to react with organic and hydroperoxyl radicals to form peroxides and alcohols, or with $\mathrm{NO}$, to form (overwhelmingly) $\mathrm{CH}_{3} \mathrm{O}$, which will react rapidly with molecular oxygen producing $\mathrm{HCHO}$ and $\mathrm{HO}_{2}$. In situ removal of $\mathrm{HCHO}$ then follows through photolysis and reaction with $\mathrm{OH}$ :

$$
\begin{aligned}
& \mathrm{OH}+\mathrm{CH}_{4} \rightarrow \mathrm{CH}_{3} \mathrm{O}_{2}+\mathrm{H}_{2} \mathrm{O} \\
& \mathrm{CH}_{3} \mathrm{O}_{2}+\mathrm{HO}_{2} \rightarrow \mathrm{CH}_{3} \mathrm{OOH}+\mathrm{O}_{2} \\
& \mathrm{CH}_{3} \mathrm{O}_{2}+\mathrm{CH}_{3} \mathrm{O}_{2} \rightarrow \mathrm{CH}_{3} \mathrm{OH}+\mathrm{HCHO}+\mathrm{O}_{2}(0.74) \\
& 2 \mathrm{CH}_{3} \mathrm{O}+\mathrm{O}_{2}(0.26)
\end{aligned}
$$




$$
\begin{aligned}
& \mathrm{CH}_{3} \mathrm{O}_{2}+\mathrm{NO} \rightarrow \rightarrow \mathrm{HCHO}+\mathrm{NO}_{2}+\mathrm{O}_{2} \\
& \mathrm{HCHO}+h v \rightarrow \mathrm{H}+\mathrm{HCO} / \mathrm{H}_{2}+\mathrm{CO} \\
& \mathrm{OH}+\mathrm{HCHO} \rightarrow \mathrm{H}_{2} \mathrm{O}+\mathrm{HCO}
\end{aligned}
$$

The rate constant for the $\mathrm{CH}_{3} \mathrm{O}_{2}$ self-reaction, (R3), is 84 times slower than that of the $\mathrm{CH}_{3} \mathrm{O}_{2}+\mathrm{HO}_{2}$ reaction at $267 \mathrm{~K}$ (the mean summertime temperature); as $\mathrm{HO}_{2}$ radicals are likely to be present at similar levels to $\mathrm{CH}_{3} \mathrm{O}_{2}$, the $\mathrm{CH}_{3} \mathrm{O}_{2}$ self-reaction makes a minor contribution to $\mathrm{CH}_{3} \mathrm{O}_{2}$ removal/HCHO production, and if this term is neglected the steady state formaldehyde concentration, considering only the $\mathrm{CH}_{4}$ source, may be approximated as:

$[\mathrm{HCHO}]_{s s}=\frac{k_{1}[\mathrm{OH}]\left[\mathrm{CH}_{4}\right]\left(k_{4}[\mathrm{NO}]\right) /\left(k_{2}\left[\mathrm{HO}_{2}\right]+k_{4}[\mathrm{NO}]\right)}{j_{5}+k_{6}[\mathrm{OH}]}$

Applying the mean observed levels for $\mathrm{OH}$ $\left(3.9 \times 10^{5} \mathrm{~cm}^{-3}\right.$; Bloss et al., 2007), NO (7.3 pptv; Jones et al., 2007), $\mathrm{HO}_{2}$ (0.76 ppt; Bloss et al., 2007) and measured HCHO photolysis rate (H. K. Roscoe, personal communication) for the CHABLIS summer measurement period, a mean formaldehyde mixing rato of $99.7 \mathrm{ppt}$ is obtained, close to the observed (summertime) mean of $127 \mathrm{ppt}$. The mean $\left(\mathrm{e}^{-1}\right)$ lifetime of $\mathrm{HCHO}$ is $13.5 \mathrm{~h}$, dominated by photolysis.

Considering the approximations adopted, and the moderate lifetime of $\mathrm{HCHO}$ in this environment, the agreement between the observed and calculated $\mathrm{HCHO}$ levels provides little evidence for any net flux of HCHO into or out of the boundary layer from elsewhere. The photochemical environment at Halley however deviates from many remote environments, in that the halogen oxides, $\mathrm{IO}$ and $\mathrm{BrO}$, may be present at appreciable concentrations. Observations during CHABLIS using a boundary layer DOAS (Saiz-Lopez et al., 2007), revealed typical mixing ratios for both species over the summer period of $2 \mathrm{ppt}$ on average (typical peaks of 5 ppt). The halogens affect the HCHO calculation above in two ways:

\section{Reaction of $\mathrm{XO}$ with $\mathrm{CH}_{3} \mathrm{O}_{2}$}

$\mathrm{XO}+\mathrm{CH}_{3} \mathrm{O}_{2} \rightarrow$ Products

Rate constants for $\mathrm{BrO}+\mathrm{CH}_{3} \mathrm{O}_{2}$ reaction of $9.14 \times 10^{-12} \mathrm{molec}^{-1} \mathrm{~cm}^{3} \mathrm{~s}^{-1} \quad(267 \mathrm{~K})$ and $5.7 \times 10^{-12}$ $(298 \mathrm{~K})$ have been reported by Enami et al. (2007) and Aranda et al. (1997) respectively, but the products of the reaction are not fully constrained: Evidence from the kinetic studies indicates that the likely products are $\mathrm{CH}_{2} \mathrm{O}_{2}+\mathrm{HOBr}$, or $\mathrm{CH}_{3} \mathrm{OBr}+\mathrm{O}_{2}$, rather than (for example) $\mathrm{CH}_{3} \mathrm{O}+\mathrm{BrO}_{2}$, which would yield $\mathrm{HCHO}+\mathrm{Br}+\mathrm{O}_{2}$. In this paper we assume that the reaction does not produce $\mathrm{HCHO}$. Measured rate constants for the $\mathrm{IO}+\mathrm{CH}_{3} \mathrm{O}_{2}$ reaction are in disagreement, with values $\left(\mathrm{molec}^{-1} \mathrm{~cm}^{3} \mathrm{~s}^{-1}\right)$ of $6 \times 10^{-11}$ (Bale et al., 2005; $298 \mathrm{~K}$ ), $2 \times 10^{-12}$ (Dillon et al., 2006;
$298 \mathrm{~K}$ ) and $6.9 \times 10^{-11}$ (Enami et al., 2006; $267 \mathrm{~K}$ ). Moreover, the products of the reaction are unknown. For the purposes of this analysis we have used a rate constant of $2 \times 10^{-12} \mathrm{molec}^{-1} \mathrm{~cm}^{3} \mathrm{~s}^{-1}$, and again assume that the reaction does not produce $\mathrm{HCHO}$.

At the observed mean summer levels of $2 \mathrm{ppt}$, following the above assumptions, the halogen oxides account for $25 \%$ of the $\mathrm{CH}_{3} \mathrm{O}_{2}$ removal rate (considering reaction with $\mathrm{NO}$, $\mathrm{HO}_{2}$, $\mathrm{IO}$ and $\mathrm{BrO}$ ), resulting in reduced steady-state $\mathrm{CH}_{3} \mathrm{O}_{2}$ levels, and hence reduced $\mathrm{HCHO}$ production.

\section{Reaction of $\mathrm{Br}$ and $\mathrm{BrO}$ with $\mathrm{HCHO}$}

$\mathrm{Br}+\mathrm{HCHO} \rightarrow \mathrm{HBr}+\mathrm{HCO}$

The $\mathrm{Br}+\mathrm{HCHO}$ reaction has a rate constant of $8.8 \times 10^{-13} \mathrm{molec}^{-1} \mathrm{~cm}^{3} \mathrm{~s}^{-1}$ (IUPAC-Atkinson et al., 2007, $267 \mathrm{~K}$ ). The observed levels of BrO during CHABLIS (DOAS), correspond to $\mathrm{Br}$ atom concentrations of approximately $0.8 \mathrm{ppt}$ on average (from steady state between $\mathrm{BrO}$ photolysis and the $\mathrm{Br}+\mathrm{O}_{3}$ reaction). The corresponding HCHO removal rate is equivalent to $90 \%$ of that from photolysis and reaction with $\mathrm{OH}$, and reduces the calculated $\mathrm{HCHO}$ lifetime to $7.2 \mathrm{~h}$. BrO may also react with $\mathrm{HCHO}$, with rate constants of $1.5 \times 10^{-14} \mathrm{molec}^{-1} \mathrm{~cm}^{3} \mathrm{~s}^{-1}$ (calculation) and $4 \times 10^{-15} \mathrm{molec}^{-1} \mathrm{~cm}^{3} \mathrm{~s}^{-1}$ (upper limit) reported by Hansen et al. (1999) and Orlando (2000) respectively. Even at the faster rate, the reaction only makes a $2 \%$ contribution to HCHO removal, and is neglected here.

Reactions (R7) ((7a) for IO, (7b) for BrO) and (R8) may be incorporated into the steady state expression for $\mathrm{HCHO}$ :

$[\mathrm{HCHO}]_{s s}=\frac{k_{1}[\mathrm{OH}]\left[\mathrm{CH}_{4}\right]\left(k_{4}[\mathrm{NO}]\right) /\left(k_{2}\left[\mathrm{HO}_{2}\right]+k_{4}[\mathrm{NO}]+k_{7 a}[\mathrm{IO}]+k_{7 b}[\mathrm{BrO}]\right)}{j_{5}+k_{6}[\mathrm{OH}]+k_{8}[\mathrm{Br}]}$

Including both of the $\mathrm{XO}+\mathrm{CH}_{3} \mathrm{O}_{2}$ and the $\mathrm{Br}+\mathrm{HCHO}$ reactions into the steady-state calculation results in an $\mathrm{HCHO}$ mixing ratio of $40 \mathrm{ppt}$, which may be compared with the observed level of $127 \mathrm{ppt}$ during the summertime period. Exploring the uncertainties in the $\mathrm{XO}+\mathrm{CH}_{3} \mathrm{O}_{2}$ kinetics, if the $\mathrm{IO}+\mathrm{CH}_{3} \mathrm{O}_{2}$ reaction were to proceed with the higher rate constant, and not lead to $\mathrm{HCHO}$ production, the steady-state $\mathrm{HCHO}$ level would be $17 \mathrm{ppt}$. If both the $\mathrm{IO}$ and $\mathrm{BrO}$ reactions with $\mathrm{CH}_{3} \mathrm{O}_{2}$ led to direct production of $\mathrm{HCHO}$, at the faster rate in the IO case, the steady state $\mathrm{HCHO}$ levels would be 55 ppt.

The presence of the iodine and particularly bromine compounds in the Antarctic boundary layer at Halley thus significantly reduces the in situ steady-state $\mathrm{HCHO}$ level expected from methane oxidation, from 99 to $17-55 \mathrm{ppt}$, depending upon the details of the halogen oxide - peroxy radical chemistry. These values are significantly lower than the observed level (127 ppt), indicating a net positive flux of $\mathrm{HCHO}$ to the Antarctic boundary layer, resulting from the combined influence of the snowpack, and the overlying atmosphere. 
Taking the in situ chemistry steady-state HCHO mixing ratio of $40 \mathrm{ppt}$ derived above, the additional $\mathrm{HCHO}$ production rate required to match the observed $127 \mathrm{ppt}$ is $8.8 \times 10^{4} \mathrm{molec}^{-3} \mathrm{~s}^{-1}$, i.e. in flux terms, assuming a 100 $\mathrm{m}$ boundary layer height typical of stable conditions at Halley (Jones et al. 2008), this is equivalent to an HCHO emission flux of $8.8 \times 10^{12}$ molec $\mathrm{m}^{-2} \mathrm{~s}^{-1}$ if the net flux in or out of the boundary layer from the overlying atmosphere is assumed to be zero. Fluxes of HCHO out of the snowpack of the order $10^{12}$ molec $\mathrm{m}^{-2} \mathrm{~s}^{-1}$ have been reported for South Pole during December (Hutterli et al., 2004), which suggests that the calculated Halley fluxes are reasonable. In addition, the Halley fluxes will be sensitive to the assumed boundary layer height, and, as noted above, implicitly assume zero exchange between the boundary layer and the free troposphere.

\section{Summary and conclusion}

Year-round measurements of $\mathrm{HCHO}$ in coastal Antarctica were obtained at Halley research station as part of the CHABLIS campaign. The data show a wintertime minimum of near, or below, the instrumental detection limit, rising to between 50 and 200 pptv during the austral summer. This seasonality is in line with the only other year-round $\mathrm{HCHO}$ dataset from coastal Antarctica, conducted at Neumayer station, but the values measured at Halley are roughly a factor 3 to 4 lower. The steady state calculations for $\mathrm{HCHO}$ presented here provide a coherent picture of the dominant controls on HCHO mixing ratios. Methane dominates the HCHO production, and other hydrocarbons, including DMS, alkenes and isoprene (which were not observed above the detection limit by the GC-FID during CHABLIS) are negligible contributors, a few percent at most. HCHO removal is dominated by photolysis and reaction with $\mathrm{Br}$ atoms. The halogen oxide $\mathrm{XO}$ reactions with $\mathrm{CH}_{3} \mathrm{O}_{2}$ may also be significant in determining the $\mathrm{HCHO}$ mixing ratio, but the data to constrain these is very uncertain. A consequence of the halogen chemistry is a reduced $\mathrm{HCHO}$ lifetime that will reduce the impact of the snowpack source of HCHO to the overlying atmosphere (in snow covered regions where the halogens are present).

Acknowledgements. The authors would like to thank the Natural Environment Research Council Antarctic Funding Initiative for providing funding for this research under grant number NER/G/S/2001/00010, and the BAS core project CACHE-CEFAC.

Edited by: J. Lee

\section{References}

Aranda, A., Le Bras, G., La Verdet, G., and Poulet, G.: The BrO $+\mathrm{CH} 3 \mathrm{O} 2$ reaction : Kinetics and role in the atmospheric ozone budget, Geophys. Res. Lett., 24, 2745-2748, 1997.

Atkinson, R., Baulch, D. L., Cox, R. A., Crowley, J. N., Hampson, R. F., Hynes, R. G., Jenkin, M. E., Rossi, M. J., and Troe, J.: Evaluated kinetic and photochemical data for atmospheric chemistry: Volume II - reactions of organic species, Atmos. Chem. Phys., 6, 3625-4055, 2006,

http://www.atmos-chem-phys.net/6/3625/2006/.

Atkinson, R., Baulch, D. L., Cox, R. A., Crowley, J. N., Hampson, R. F., Hynes, R. G., Jenkin, M. E., Rossi, M. J. and Troe, J.: Evaluated kinetic and photochemical data for atmospheric chemistry: Volume III - gas phase reactions if inorganic halogens, Atmos. Chem. Phys., 7, 981-1191, 2007, http://www.atmos-chem-phys.net/7/981/2007/.

Bale, C. S. E., Canosa-Mas, C. E., Shallcross, D. E., and Wayne, R. P.: A discharge-flow study of the kinetics of the reactions of IO with $\mathrm{CH}_{3} \mathrm{O}_{2}$ and $\mathrm{CF}_{3} \mathrm{O}_{2}$, Phys. Chem. Chem. Phys., 7, 2164 2172, 2005.

Beine, H. J., Amoroso, A., Dominé, F., King, M. D., Nardino, M., Ianniello, A., and France, J. L.: Surprisingly small HONO emissions from snow surfaces at Browning Pass, Antarctica, Atmos. Chem. Phys., 6, 2569-2580, 2006,

http://www.atmos-chem-phys.net/6/2569/2006/.

Bloss, W. J., Lee, J. D., Heard, D. E., Salmon, R. A., Bauguitte, S. J.-B., Roscoe, H. K., and Jones, A. E.: Observations of $\mathrm{OH}$ and $\mathrm{HO}_{2}$ radicals in coastal Antarctica, Atmos. Chem. Phys., 7, 4171-4185, 2007, http://www.atmos-chem-phys.net/7/4171/2007/.

Burkhart, J. F., Hutterli, M. A., and Bales, R. C.: Partitioning of formaldehyde between air and ice at $-35^{\circ} \mathrm{C}$ to $-5^{\circ} \mathrm{C}$, Atmos. Environ., 36, 2157-2163, 2002.

Chen, G., Davis, D., Crawford, J., Hutterli, L. M., Huey, L. G., Slusher, D., Mauldin, L., Eisele, F., Tanner, D., Dibb, J., Buhr, M., McConnell, J., Lefer, B., Shetter, R., Blake, D., Song, C. H., Lombardi, K., and Arnoldy, J.: A reassessment of $\mathrm{HO}_{\mathrm{x}}$ South Pole chemistry based on observations recorded during ISCAT 2000, Atmos. Environ., 38, 5451-5461, 2004.

Chen, G., Huey, L. G., Crawford, J. H., Olson, J. R., Hutterli, M. A., Sjostedt, S., Tanner, D., Dibb, J., Lefer, B., Blake, N., Davis, D., and Stohl, A.: An assessment of the polar $\mathrm{HO}_{\mathrm{x}}$ photochemical budget based on 2003 Summit Greenland field observations, Atmos. Environ., 41, 7806-7820, 2007.

Couch, T. L., Sumner, A. L., Dassau, T. M., Shepson, P. B., and Honrath, R. E.: An Investigation of the Interaction of Carbonyl Compounds with the Snowpack, Geophys. Res. Lett., 27, 22412244, 2000.

Dassau, T. M., Sumner, A. L., Koeniger, S. L., Shepson, P. B., Yang, J., Honrath, R. E., Cullen, N. J., Steffen, K., Jacobi, H.-W., Frey, M., Bales, R. C., Investigation of the role of the snowpack on atmospheric formaldehyde chemistry at Summit, Greenland, J. Geophys. Res., 107(D19), 4394, doi:10.1029/2002JD002182, 2002.

De Serves, C.: Gas phase formaldehyde and peroxide measurements in the Arctic atmosphere, J. Geophys. Res., 99, 25391 $25398,1994$.

Dillon, T. J., Tucceri, M. E., and Crowley, J. N.: Laser induced fluorescence studies of iodine oxide chemistry, Phys. Chem. Chem. 
Phys., 8, 5185-5198, 2006.

Dlugokencky, E. J., Lang, P. M., and Masarie, K. A.: Atmospheric Methane Dry Air Mole Fractions from the NOAA ESRL Carbon Cycle Cooperative Global Air Sampling Network, 1983-2006, Version: 2007-09-19, ftp://ftp.cmdl.noaa.gov/ccg/ ch4/flask/event/, 2007.

Dong, S. and Dasgupta, P. K.: Fast Fluorometric Flow Injection Analysis of Formaldehyde in Atmospheric Water, Environ. Sci. Technol., 21, 581-588, 1987.

Dasgupta, P. K., Dong, S., Hwang, H., Yang, H.-C., and Genfa, Z.: Continuous Liquid-Phase Fluorometry Coupled to a Diffusion Scrubber for the Determination of Atmospheric Formaldehyde, Hydrogen Peroxide and Sulfur Dioxide, Atmos. Environ., 22, 949-963, 1988.

Enami, S., Yamanaka, T., Hashimoto, S., Kawasaki, M., Nakano, Y., and Ishiwata, T.: Kinetic Study of IO Radical with $\mathrm{RO}_{2}(\mathrm{R}=$ $\mathrm{CH}_{3}, \mathrm{C}_{2} \mathrm{H}_{5}$, and $\mathrm{CF}_{3}$ ) Using Cavity Ring-Down Spectroscopy, J. Phys. Chem. A, 110, 9861-9866, 2006.

Enami, S., Yamanaka, T., Nakayama, T., Hashimoto, S., Kawasaki, M., Shallcross, D. E., Nakano, Y., and Ishiwata, T.: A Gas-Phase Kinetic Study of the Reaction between Bromine Monoxide and Methylperoxy Radicals at Atmospheric Temperatures, J. Phys. Chem. A, 111, 3342-3348, 2007.

Grannas, A. M., Shepson, P. B., Guimbaud, C., Sumner, A. L., Albert, M., Simpson, W., Dominé, F, Boudriese, H., Bottenheim J., Beine, H J, Honrath, R., and Zhou, X.: A study of photochemical and physical processes affecting carbonyl compounds in the Arctic atmospheric boundary layer, Atmos. Environ., 36, 15-16, 2733-2742, 2002.

Grannas, A. M., Shepson, P. B., and Filley, T. R.: Photochemistry and nature of organic matter in Arctic and Antarctic snow, Global Biogeochem. Cy., 18, GB1006, doi:10.1029/2003GB002133, 2004.

Hansen, J. C., Li, Y., Francisco, J. S., and Li, Z.: On the Mechanism of the $\mathrm{BrO}+\mathrm{CH}_{2} \mathrm{O}$ Reaction, J. Phys. Chem. A, 103, 8543$8546,1999$.

Hutterli, M. A., Bales, R. C., McConnell, J. R., and Stewart, R. W.: HCHO in Antarctic Snow: Preservation in Ice Cores and Air-Snow Exchange, Geophys. Res. Lett., 29, 1235, doi:10.1029/2001GL014256, 2002.

Hutterli, M. A., Bales, R. C., and Röthlisberger, R.: Atmosphereto-snow-to-firn transfer studies of HCHO at Summit, Greenland, Geophys. Res. Lett., 26, 1691-1694, 1999.

Hutterli, M. A., McConnell, J. R., Chen, G., Bales, R. C., Davis, D. D., and Lenschow, D. H.: Formaldehyde and hydrogen peroxide in air, snow and interstitial air at South Pole, Atmos. Environ., 38, 5439-5450, 2004.

Hutterli, M. A., McConnell, J. R., Stewart, R. W., and Bales, R. C.: Sensitivity of hydrogen peroxide and formaldehyde preservation in snow and firn to changing ambient conditions: Implications for the interpretation of ice-core records., J. Geophys. Res., 108, 4023, doi:10.1029/2002JD002528, 2003.

Hutterli, M. A., McConnell, J. R., Stewart, R. W., Jacobi, H.-W., and Bales, R. C.: Impact of temperature-driven cycling of hydrogen peroxide $\left(\mathrm{H}_{2} \mathrm{O}_{2}\right)$ between air and snow on the planetary boundary layer, J. Geophys. Res., 106, 15 395-15 404, 2001.

Jacob, D. J., Field, B. D., Li, Q., Blake, D. R., de Gouw, J., Warneke, C., Hansel, A., Wisthaler, A., Singh, H. B., and Guenther, A.: Global budget of methanol: Constraints from atmospheric observations, J. Geophys. Res., 110, D08383, doi:10.1029/2004JD005172, 2005.

Jacobi, H.-W., Frey, M. M., Hutterli, M. A., Bales, R. C., Schrems, O., Cullen, N. J., Steffen, K., and Koehler, C.: Long-term measurements of hydrogen peroxide and formaldehyde exchange between the atmosphere and surface snow at Summit, Greenland, Atmos. Environ., 36, 2619-2628, 2002.

Jones, A. E., Wolff, E. W., Ames, D., Bauguitte, S. J.-B, Clemitshaw, K., Fleming, Z., Mills, G., Saiz-Lopez, A., Salmon, R. A., Sturges, W., and Worton, D.: The multi-seasonal $\mathrm{NO}_{\mathrm{y}}$ budget in coastal Antarctic and its link with surface snow and ice core nitrate: results from the CHABLIS campaign, Atmos. Chem. Phys. Discuss., 7, 4127-4163, 2007,

http://www.atmos-chem-phys-discuss.net/7/4127/2007/.

Jones, A. E., Wolff, E. W., Salmon, R. A., Bauguitte, S. J.-B., Roscoe, H. K., Anderson, P. S., Ames, D., Clemitshaw, K. C., Fleming, Z. L., Bloss, W. J., Heard, D. E., Lee, J. D., Read, K. A., Hamer, P., Shallcross, D. E., Jackson, A. V., Walker, S L., Lewis, A. C., Mills, G. P., Plane, J. M. C., Saiz-Lopez, A., Sturges, W. T., and Worton, D. R.: Chemistry of the Antarctic Boundary Layer and the Interface with Snow: an overview of the CHABLIS campaign, Atmos. Chem. Phys., 8, 3789-3803, 2008, http://www.atmos-chem-phys.net/8/3789/2008/.

König-Langlo, G., King, J., and Pettre, P.: Intercomparison of the climatology from the three coastal Antarctic stations Dumont d'Urville, Neumayer, and Halley with respect to aerosol and snowfall chemistry, J. Geophys. Res., 103, 10 935-10 946, 1998.

Lee, Y.-N., Zhou, X., Kleinman, L., Nunnermacker, L., Springston, S, Daum, P., Newman, L., Keigley, W., Holdren, M., Spicer, C., Young, V., Fu, B., Parrish, D., Holloway, J., Williams, J., Roberts, J., Ryerson, T., Fehsenfeld, F., Atmospheric chemistry and distribution of formaldehyde and several multioxygenated carbonyl compounds during the 1995 Nashville\&sol;Middle Tennessee Ozone Study, J. Geophys. Res, 103(D17), 22449 22 462, 1998.

Orlando, J. J., Ramacher, B., and Tyndall, G. S.: Upper limits for the Rate Coefficients for Reactions of $\mathrm{BrO}$ with Formaldehyde and HBr, Geophys. Res. Lett., 27, 2633-2636, 2000.

Read, K. A., Lewis, A. C., Salmon, R. A., Jones, A. E., and Bauguitte, S.: OH and halogen atom influence on the variability of nonmethane hydrocarbons in the Antarctic Boundary Layer, Tellus B, 59, 22-38, 2007.

Riedel, K., Weller, R., and Schrems, O.: Variability of formaldehyde in the Antarctic troposphere, Phys. Chem. Chem. Phys., 1, 5523-5527, 1999.

Riedel, K., Allan, W., Weller, R., and Schrems, O.: Discrepancies between formaldehyde measurements and methane oxidation model predictions in the Antarctic troposphere: An assessment of other possible formaldehyde sources, J. Geophys. Res., 110, 15308, doi:10.1029/2005JD005859, 2005.

Saiz-Lopez, A., Mahajan, A. S., Salmon, R. A., Bauguitte, S. J.-B., Jones, A. E., Roscoe, H. K., and Plane, J. M. C.: Boundary layer halogens in coastal Antarctica, Science, 317, 348-351, 2007.

Shepson, P. B., Sirju, A.-P., Hopper, J. R., Barrie, L. A., Young, V., Niki, H., and Dryfhout, H.: Sources and sinks of carbonyl compounds in the Arctic Ocean boundary layer: Polar ice floe experiment, J. Geophys. Res., 101, 21 081-21 089, 1996.

Sjostedt, S. J., Huey, L. G., Tanner, D. J, Peischl, J., Chen, G., Dibb, J. E., Lefer, B., Hutterli, M. A., Beyersdorf, A. J., Blake, N. J., 
and Blake, D. R.: Peroxy and Hydroxyl Radical Measurements During the Spring 2004 Summit Field Campaign, Eos Trans. AGU, 86(56), Fall Meet. Suppl., Abstract A24A-02, 2005.

Sjostedt, S. J., Huey, L. G., Tanner, D. J., Peischl, J., Chen, G., Dibb, J. E., Lefer, B., Hutterli, M. A., Beyersdorf, A. J., Blake, N. J., Blake, D. R., Sueper, D., Ryerson, T., Burkhart, J., and Stohl, A.: Observations of hydroxyl and the sum of peroxy radicals at Summit, Greenland during summer 2003, Atmos. Environ., 41, 5122-5137, 2007.

Staffelbach, T., Neftel, A., Stauffer, B., and Jacob, D.: A record of the atmospheric methane sink from formaldehyde in polar ice cores, Nature, 349, 603-605, 1991.

Sumner, A. L., Shepson, P. B., Grannas, A. M., Bottenheim, J. W., Anlauf, K. G., Worthy, D., Schroeder, W. H., Steffen, A., Domine, F., Perrier, S., and Houdier, S.: Atmospheric chemistry of formaldehyde in the Arctic troposphere at Polar Sunrise, and the influence of the snowpack, Atmos. Environ., 36, 2553-2562, 2002.

Sumner A. L. and Shepson, P. B.: Snowpack production of formaldehyde and its effect on the Arctic troposphere, Nature, 398, 230-233, 1999.
Wert, B. P., Trainer, M., Fried, A., Ryerson, T. B., Henry, B., Potter, W., Angevine, W. M., Atlas, E., Donnelly, S. G., Fehsenfeld, F. C., Frost, G. J., Goldan, P. D., Hansel, A., Holloway, J. S., Hubler, G., Kuster, W. C., Nicks Jr., D. K., Neuman, J. A., Parrish, D. D., Schauffler, S., Stutz, J., Sueper, D. T., Wiedinmyer, C., and Wisthaler, A.: Signatures of terminal alkene oxidation in airborne formaldehyde measurements during TexAQS 2000, J. Geophys. Res, 108(D3), 4104, doi:10.1029/2002JD002502, 2003.

Yang, J., Honrath, R. E., Peterson, M. C., Dibb, J. E., Sumner, A. L., Shepson, P. B., Frey, M., Jacobi, H.-W., Swanson, A., and Blake, N.: Impacts of snowpack emissions on deduced levels of $\mathrm{OH}$ and peroxy radicals at Summit, Greenland, Atmos. Environ., 36, 2523-2534, 2002.

Zhou, X., Beine, H. J., Honrath, R. E., Fuentes, J. D., Simpson, W., Shepson, P. B., and Bottenheim, J.: Snowpack photochemical production as a source for HONO in the Arctic boundary layer in spring time, Geophys. Res. Lett., 28(21), 4087-4090, 2001. 